\title{
US Geological Survey picks up the NBS pieces
}

\section{US superconductor research is good value - so far}

Providence, Rhode Island. A bold experiment to engage US government scientists in the systematic study of ecosystems will end quietly next month, when the two-year-old National Biological Service (NBS) is abolished and its operations transferred to the US Geological Survey (USGS).

Sixteen hundred staff at NBS's 40 field stations will become the Biological Resources Division of the USGS from October. Many of them are optimistic that they will be able to work more closely with hydrologists, geologists and map-makers in the USGS. But the change marks the defeat of the contentious plan of Bruce Babbitt, the interior secretary, to establish a powerful new agency dedicated to ecology (see Nature 365, 479; 1993 \& 367, 400; 1994).

Ron Pulliam, the director of the NBS, intends to return to the University of Georgia, having declined to lead the new USGS division. He joined NBS in Washington two years ago to lead an extensive new project,

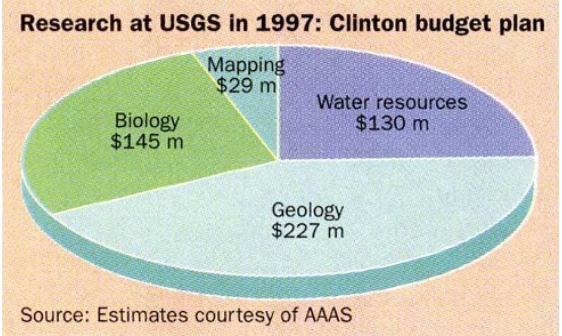

but has spent his time locked in a battle with Congress for his agency's survival. But he told NBS staff at the annual meeting of the Ecological Society of America in Providence, Rhode Island, that the USGS was "a good, safe place" for them to end up.

The NBS was founded as the National Biological Survey in 1994 from the science operations of three agencies of the Department of the Interior - the Fish and Wildlife Service, the Bureau of Land Management and the National Park Service. The plan was to expand these operations to form an agency that would focus on ecology and biodiversity.

But the plan quickly ran into serious political trouble. Even the Democratcontrolled Congress of 1993-94 sided with landowners who feared the impact of the NBS on land use. In a doomed bid to assuage this fear, the agency was renamed the National Biological Service.

The Republican Congress elected in November 1994 moved quickly to abolish the NBS, but it did not want to close the field stations (these are cleverly scattered across 38 states) and instead found a home for them in the USGS.
Gordon Eaton, director of USGS which was itself threatened with abolition at the outset of this Congress, until the new majority discovered what the agency actually does - says he is "quite bullish on this marriage". $\mathrm{He}$ says he is "very excited about all the opportunities" that will arise for collab-

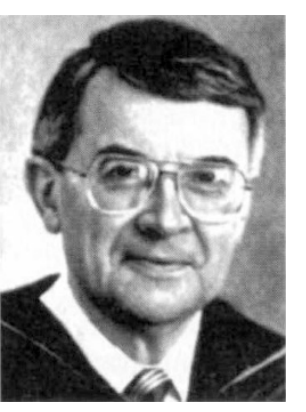

Gordon Eaton: time to think big. oration with the new division.

But Eaton acknowledges that morale among the staff has hit rock bottom. "These people have been through hell," he says, noting that they were uprooted from their old agencies, "promised a grand new future", and are now being uprooted again. "But they are beginning to see that they'll get more respect here than they did in the agencies they originated from," he says.

Within the enlarged USGS, the Water Resources Division will remain the dominant division, with 5,000 staff. Geology, mapping and the new biology division each have around one-third as many people. In terms of research, however, the new division will be the second largest in USGS, accounting for about 30 per cent of all research there (see pie chart).

The enlarged USGS, embracing more than 90 per cent of all research at the Department of the Interior, may be the shape of things to come in the federal government, says Eaton. "There will be fewer, larger units, and they will be multi-disciplinary," he predicts.

Some biologists joining the agency are worried about USGS publication rules, which they say will make it hard to present new science without going through months of internal review. But agency officials say that the new division will retain autonomy in this and other administrative matters. On the whole, NBS staff at the Ecological Society meeting were enthusiastic about the change, and the opportunities it brings, especially in mapping and hydrology.

The change may bring some stability to their lives. But their identity crisis could resume soon: Eaton and others think that the USGS's name should eventually change, to something like the National Natural Resources Agency, to reflect the agency's interests beyond rocks. Babbitt is against the change, however, understandably fearing that it would risk attracting more unwanted attention from the Congress.

Colin Macilwain
Washington. A \$50 million US programme to develop power applications for superconductors has chalked up impressive successes, despite being only half the size of a comparable programme in Japan, says a US panel that compared the two. The US Department of Energy programme has achieved "very good coupling of government and industry funding, and of applications people and fundamental research people," says David Larbalestier of the materials science department at the University of Wisconsin at Madison, who chaired the panel.

But the Japanese programme benefits from stable funding and "a strong national belief that superconductivity will be vital 21st century technology" according to a preliminary summary of the study, conducted for the World Technology Evaluation Center (WTEC), a government-funded group based at Loyola College in Baltimore, Maryland.

Japan will ultimately benefit from its approach of seeking applications for established, metal low-temperature superconductors (LTS) as well as for the more exotic, ceramic high-temperature superconductors (HTS), the panel reports. Recent advances enabling LTS materials to be supercooled by a refrigerator, removing the need for a flow of liquid helium, will increase the practical value of these materials, Larbalestier says.

The panel also reviewed the German programme, the third largest national effort. This has improved over the past four years, but according to Larbalestier is "not leading in any major area". Germany's spending is close to that of the United States at $\$ \mathbf{4 0}$ million annually. Japan spends $\$ 100$ million annually on power applications of superconductors, and the work also benefits from Japan's huge effort to develop new Maglev (magnetic levitation) trains.

Superconductor application research was rescued from near obscurity in 1986 by the discovery of a new class of ceramics that could conduct electricity without resistance at far higher temperatures than the established, metal-alloy superconductors. "The tenth anniversary is coming up," says Larbalestier. "A lot of promises were made that really had no hope of being put into action." Progress in perfecting the new materials has been steady but unspectacular.

US successes noted by the panel include a 150-kW electric motor and a 50-m-long power cable, each using HTS and each developed in a partnership between Department of Energy laboratories, universities and the electricity supply industry.

But the panel is worried that funding from the politically contentious renewable energy division of the department - "has to be fought for each year". 